\title{
The Digitalization of Public Service Assurance
}

\author{
${ }^{1}$ HERU ROCHMANSJAH, ${ }^{2}$ KARNO \\ ${ }_{1,2}$ Institute of Governance of Home Affair, Ir. Soekarno Km. 20 Jatinangor-Sumedang, Indonesia \\ correspondence author: heru_rochmansjah@ipdn.ac.id
}

\begin{abstract}
The digitalization of public service assurance is a factor that determines the quality of public service to meet the expectations and desires of the citizens. Public service assurance needs to be supported by digital-based information systems. This research applies a mixed-method approach, starting with a quantitative approach, and continues with a qualitative approach. This study has 273 respondents and 17 informants. The quantitative research data analysis uses SEM analysis, qualitative data analysis uses QDA analysis, and score distribution analysis uses SPSS. The result of this research is the conceptualization of information systems including dimensions of human resources, information technology, and information relations. The concept of causality relationship between information systems and the quality of health services indicated by the loading factor value of 0.51 , which can be stated that the relationship is significant and produces a new concept of digital-based Public Service Assurance. This research concludes there is a positive and significant influence between information systems and the quality of public services. Furthermore, the new concept can be synthesized into a study of public services in scientific work.
\end{abstract}

Keywords: information system, service assurance, digitalization of service

\section{Introduction}

Public services assurance can be carried out through the quality of public services. This paradigm demands public service providers to provide not only quality servitces but also the assurance of public services to the citizens/ communities.

Public service Assurance is expected to be able to provide service Assurance in accordance with Standard Operational Procedure (SOP) and can be measured quantitatively and qualitatively (Aagja and Garg, 2010). Public service Assurance is not only shown in the form of numbers but also changes in the behavior of service recipients, in this case, the community/citizens.

Public Service Assurance is a model of public service where one of the factors is influenced by the information system (digitalization). Digitalization is the use of digital technology to change business models to the ones that provide new income and value generating opportunities with the aim to have a clear relationship between the service offered and the customer's actual needs (Gray \& Rumpe, 2015). Digitalization encompasses 3 components, namely Technology, Information, and Communication, abbreviated as ICT (Ayanso, Cho, \& Lertwachara, 2010; Agamba \& Keengwe, 2012). Digitalization of service is often called E-Services (Taherdoost et al., 2013).

Digitalization determines the success of public service delivery in providing guarantees to service recipients, both quantitatively and qualitatively. This model is a research finding (Karno, I. Adi, B. Laksmono, 2018).

A research conducted by (Karno, Adi, and Laksmono, 2018) stated that the overview of public services in Sragen Regency is a phenomenon influenced by various factors. The phenomenon is explored in order to answer the following research questions of "What is the influence of information system on the intended public service and how does the information system affect the intended public service?". The questions are designated to analyze the influence of information systems on health services at

Received: 2020-03-28, Revised: 2020-05-05, Accepted: 2020-06-03. 
Puskesmas (Community Health Center Unit) Kedawung in Sragen Regency in order to be able to assure services to the community. From a theoretical point of view, the new concept is expected to provide useful inputs or ideas that can be implemented by the head of the Puskesmas, the Sragen Regional Government, and the Central Government (Karno, I. Adi, B. Laksmono, 2018).

The phenomenon being studied is related to the quality of Puskesmas as an effort to improve the affordability of Puskesmas to the community. To realize that, the local government is required to build Desa Siaga (Alert Village) and put Village Birth Attendants (health workers) in each village/ urban village totaling 208 villages (Pemda Sragen, 2008). The following figure 1 is a pie chart of the percentage of childbirth assisted by health workers in Sragen Regency.

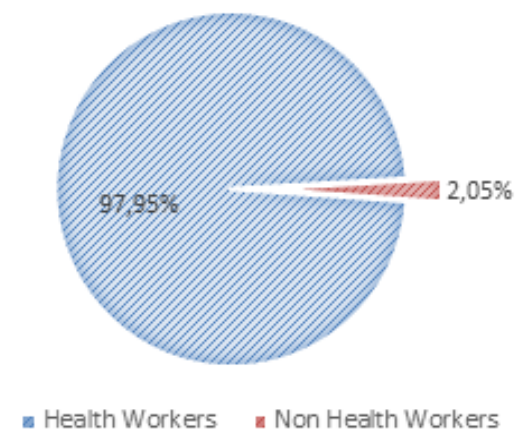

Figure 1

The Percentage of Childbirth Assistance in Sragen Regency

Figure 1 shows that childbirth assistance performed by health workers has reached $97,95 \%$ and can be categorized very well.

The total number of Puskesmas in Sragen Regency is 26. The number of Puskesmas provides 24-hour emergency services can be seen in figure 2 below.

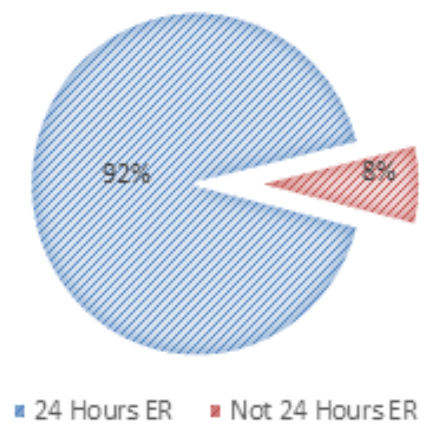

Figure 2

Emergency Services at Puskesmas in Sragen Regency
Figure 2 shows there are 24 Puskesmas provide emergency services, while Puskesmas that do not provide emergency services is 12 .

Figure 3 is the percentage of Puskesmas that provide inpatient service/care facilities.

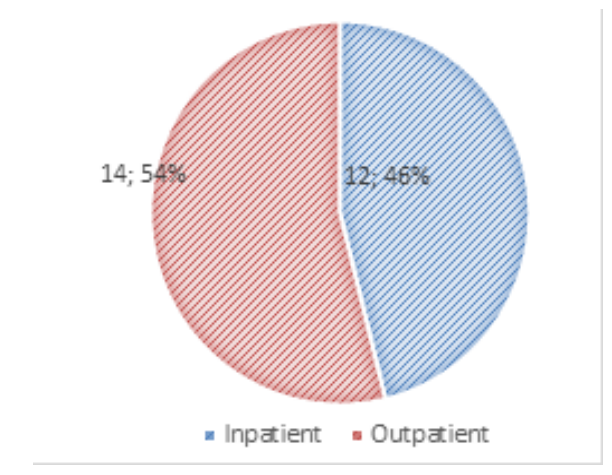

Figure 3

Inpatient Services/Care at Puskesmas in Sragen Regency

Figure 3 shows the number of Puskesmas that have provided inpatient services/care is $12(46 \%)$ and Puskesmas that have not yet provided inpatient services are 14 (54\%).

The service information system is a change of service from conventional to digital which called digitalization. Digitalization is the use of digital technology to change business models that can provide new income and opportunities to generate value with the aim to find a clear relationship between the service offered and the customer's actual needs (Gray \& Rumpe, 2015). The results show that PPM Pulse Position Modulation is the most effective modulation in comparison with others (Basudewa,MI, et al 2020)

Digitalization requires Information, Communication, and Technology (ICT) to achieve the objectives of the information system optimally (Ayanso, Cho, \& Lertwachara, 2010; Agamba \& Keengwe, 2012). Effective digitalization of services is also called E-Services (Taherdoost et al., 2013).

ICT has a more significant role in the post-2015 development agenda to achieve the goals of sustainable development (SDG) in the future when the world moves faster towards a digital society. ICT has a mission to connect everyone and create an information society that is truly inclusive with measurable progress (ICT, 2015).

Developing ICTs will be attractive for people and can help the governments to build 
a more inclusive environment. In this context, social electronics (e-Social) are developed to help run a democratic system of government effectively (Valaskakis, 2011). Government and private institutions that focus on services have begun to develop and implement E-Services to expand the effectiveness and efficiency of their performance. This expansion and evolution significantly influence customer behavior (Sharma, 2007).

E-Services are important for consumers because they can provide several benefits, namely strengthening the service provider relationships with customers, making efficient transactions, and increasing customer satisfaction (Taherdoost et al., 2013).

The benefits citizens get when they start using the new information communication technology (ICT) platform are the reduced cost and the increase of communication efficiency. The use of ICTs changes the stories of success that put on hold become an increase of longterm accountability, specifically the quality and content of reports and responses provided by users and stakeholders (Grossman et al., 2018).

A computerized information system is a set of components that are organized and interrelated or interact comprehensively to build or process data into useful information (Bodnar, 2000; Jogiyanto, 1995).

To make quick decisions, information systems require information resources as follows: (a) computer hardware; (b) computer software; (c) information specialties; (d) users; (e) facilities; (e) databases; and ( $f$ ) information (McLoad, 1996).

According to Indrajit (2004), those resources are included in the three I/T Assets: human resources, technology, and relations. Human resources include competence, performance, collaboration, and responsibility of the information system manager. Technology includes hardware reliability, software reliability, hardware and software integration, and effectiveness of the application of information technology. Relations or relationships include relationships between information systems, the relationship between decision-making systems, the relationship between policy implementation systems, and the relationship between information systems and clients.

The gap in perception of service quality occurs between the information technology service providers (IT) and service recipients (clients). IT services require a high investment to increase the accuracy of effectiveness analysis. Opportunities to improve service quality through information technology from the perspective of strategy adjustments are mainly carried out on dimensions related to public services including physical evidence, reliability, responsiveness, assurance, and empathy (Roses et al., 2009).

The description above shows that the success of public services is strongly influenced by the information systems with information, Education, and Technology (ICT) as the basis of digitalization. In line with the opinion of (Kim \& Oh, 2012), Malcolm Baldrige Model known as seven critical states that business results are leadership, strategic planning, customer and market focus, information and analysis, human resource focus, and process management. In this context, the information system is defined as a series of analysis processes to obtain information (information and critical analysis).

For service quality, according to (Ograjenšek, 2008), there are 2 approaches of statistical methods in improving service quality, namely the production approach, which uses traditional quality control statistics; and marketing approach, which is built based on social sciences.

Quality is a strategic tool for achieving operational efficiency and improving business performance for both services and goods. Different definitions of the term 'service quality' have been proposed with different service measurement scales. SERVQUAL (Service Quality) and SERVPERF (Service Performance) are the two main service quality measurement scales. Empirically, in terms of evaluating the validity, reliability, and methodology of service quality scales, SERVPERF clearly shows its excellence since it can measure perceptions, expectations, and performance (Ograjenšek, 2008).

Internal and external factors such as the availability of resources, patient cooperation, and collaboration between providers affect service quality and service outcomes. Leadership support, proper planning, education and training, and effective management of resources and processes can improve service quality (Mosadeghrad, 2014).

Previous service quality measured by the SERVQUAL instrument (Zeithaml, et al., 1990) only reflects the service delivery process. Empirically, according to 
the perspective of (Kang \& James, 2004), service quality consists of three dimensions, namely technical, functional, and image. Images function as filters in service quality. The Granroos model is a more precise representation of service quality with a limited concentration on functional quality dimensions.

The basic theories and conceptual definitions of variables of service quality. According to (Zeithaml et al., 1990), there are 5 attributes of customer satisfaction, namely (1) physical evidence; (2) responsiveness; (3) assurance; (4) empathy; and (5) reliability. Based on this theoretical basis, a conceptual definition of a variable is stated as follows: the Quality of Health Service is a characteristic of Health Services at Puskesmas Kedawung in Sragen Regency. The public is given access to and the right to public information which is a human right and guaranteed by law (Rachmiatie, Hasbiansyah, Khotimah, \& Ahmadi, 2013)

\section{Research Methodology}

This study uses a mixed method of quantitative and qualitative research approaches. The quantitative approach is used to test the causality relationship of research hypotheses, while the qualitative approach is used to deepen the results of hypothesis testing (the depth hypothesis) of quantitative research. In addition, to strengthen this research, quantitative research is also used for the distribution of perception scores of service recipients. Thus, this study uses 3 research methods which called the method of triangulation approach (Tashakkori \& Teddlie, 2010; Neuman, 2006; Johnson and Onwuegbuzie 2004).

The sample of this study is 273 respondents obtained from a population of 857 people. Data collection uses questionnaires, interviews, observations, and literature studies. For data analysis, this study uses SEM (Structural Equation Modeling) analysis for quantitative research data, QDA analysis (Qualitative Data Analysis) for qualitative research data, and SPSS (Statistical Package for the Social Sciences) analysis for distribution of score data. Then the results of the three research approaches are integrated during the discussion.

\section{Results And Discussion}

\section{The Results of Research}

This study aims to analyze the influence of information systems on health services at Puskesmas Kedawung to be able to provide assurance of services to the community. The aim is broken down into the magnitude of the influence of information systems on health services and the contribution of the information system to the health service assurance at Puskesmas Kedawung in Sragen Regency.

Information systems affect health services. In line with the results of quantitative research by (Karno, I. Adi, B. Laksmono, 2018), from the measurement of structural models and testing hypotheses, the results of the causal relationship between independent and dependent variables (the quality of Puskesmas Health services) are listed in Table 1.

Table 1

The Relationship between Independent Variable and Dependent Variable

\begin{tabular}{llll}
\hline No. & Independent Variable & Path & T-value \\
1. & SPM Policy & 0,37 & 2,92 \\
& Implementation & & \\
2. & Allocation of Fund & 0,40 & 3,15 \\
3. & $\begin{array}{l}\text { Implementation of } \\
\text { Capacity Building }\end{array}$ & 0,49 & 3,96 \\
& & \\
Program & & \\
4. & Reward System & 0,44 & 3,58 \\
5. & Personality Attribute & 0,44 & 3,64 \\
6. & Leadership & 0,59 & 4,49 \\
7. & Information System & 0,51 & 3,98 \\
8. & Client Orientation & 0,80 & 5,62 \\
\hline
\end{tabular}

Source: Researcher's processing results, Karno, 2014

The results of the study in Table 1 above show that the value of the causality relationship of 8 variables is significant. This can be seen from the T-Value of each variable that is greater than 1.96 with a confidence level of 95\% (Hair et al. in Wijanto, 2008). The results of the path coefficient show that the causality relationship of 8 variables that have a path value greater than 0.5 (Hair et al. in Wijanto, 2008) is a Dominant variable. Thus, the dominant variables are the variable of Leadership, Information Systems, and Client Orientation. This perspective is appropriate, where one of the significant variables ( $T$-Value 3.98) and dominant (path 0.51 ) is the Information System. 
Based on the results of the measurement of the structural equation model, information system theory from (Indrajit, 2004) as the basis for drafting an independent variable concept is suitable for uncovering and discussing the problems of information systems. Likewise, the Servqual theory of (Zeithaml et al., 1990) as the basis for the preparation of dependent variables is suitable for uncovering and discussing the quality of health services. From these matches, it can be concluded that the concept of research and hypothesis testing using the theory in accordance with the research problem will obtain a significant causal relationship. The significance can be seen from the path value of 0.51 which is greater than 0.5 reference value; and T-Value of 3.98 which is greater than 1.96 reference value (Karno, I. Adi, B. Laksmono, 2018).

The research results of (Karno, I. Adi, B. Laksmono, 2018) explain the measurement model of the Information System variable as shown in Table 2.

\begin{tabular}{lll}
\multicolumn{3}{c}{$\begin{array}{c}\text { Table } 2 \\
\text { The Measurement Model of Information } \\
\text { System }\end{array}$} \\
\hline Dimension & Loading & t-value \\
\hline Human Resources & 0,75 & 7,81 \\
Information Technology & 0,70 & 7,52 \\
Information Service & 0,82 & 7,89 \\
Relations & & \\
\hline
\end{tabular}

Source: Researcher's processing results, Karno, 2014

According to the table above, the dominant priority order of Dimension based on loading factors are (1) Information service relations; (2) information technology, and (3) human resources (Indrajit, 2004).

The measurement model results in the table above show that the loading value of 3 factors has a strong correlation with the construction of the information system variable. This can be seen from the 3 dimensions that have given a significant loading value on the Information System variable. In the information system, the most dominant factor with the highest loading value $(0.82)$ is the dimension of information service relations (Karno, I. Adi, B. Laksmono, 2018).

This significance is known from the 3 dimensions which have a $\mathrm{t}$-value greater than the Cut off value of 1.96 (Hair et al. in Wijanto, 2008). Thus, the 3 dimensions in the Information System have a significant relationship with the construct and manifest and can be declared valid.

Based on the results of loading factor of the Information System variable in the table above, the 3 dimensions have a loading factor value greater than 0.5 (Hair et al. in Wijanto, 2008); then it can be stated that these 3 dimensions are dominant in the process of forming the influence of the Information System on the Quality of Health Services (Karno, I. Adi, B. Laksmono, 2018).

The concept as a research finding that has been described previously is "Public Service Assurance in Information Systems Perspectives".

The concept is reinforced by the results of research on the distribution of respondents 'scores on the quality of health services in which all respondents' answers are included in the "Sae" (good) category. These results are statements that can assure public trust in health service Assurances that can fulfill patient expectations, thereby building strong trust in health services (Karno, I. Adi, B. Laksmono, 2018).

The conceptualization is "Health Services Assurance assures the ability to serve optimally, being polite in serving professionally, and can be trusted by the service recipient because service providers are able to provide services that fulfill the expectations through the implementation of information systems" (Karno, I. Adi, B. Laksmono, 2018).

\section{Digitalization of Public Service Assurance}

Based on the results of the study, the implementation of public services (in this case, Puskesmas) must be clearly regulated, directed by using an information system which becomes a determining factor indicated by a loading factor of 0.51 . Conceptually, an information system is a series of producing information processes with digital support that includes information and Communication Technology - ICT (Morrar and Arman, 2017; (Taherdoost et al., 2013).

One of the dimensions of the information system is the service information relation that is able to provide trust to the customer (people who seek treatment) as the service recipient indicated by a loading factor of 0.82 as shown in table 2 . This information relation 
is in line with the Health Belief Model as stated by (Edberg, 2007) as follows:

... health-seeking and other health behavior was thought to be motivated by four factors: (1) Perceived susceptibility; (2) Perceived severity; (3) Perceived benefits of an action; (4) Perceived barriers to taking that action.

The concept underlies the behavior of health services as an object in this study which determined by personal beliefs or perceptions about diseases and existing strategies to reduce the occurrence of disease (Hochbaum, 1958 in (Rosenstock, 1996). Personal perceptions in this study are influenced by motivational factors, namely (1) Perception of vulnerability; (2) Perception of severity; (3) Perception of the benefits of an action; and (4) Perception of obstacles to taking action.

Changes in behavior in health services are also caused by psychological models developed by (Rosenstock, 1996). This study shows that patients (as the recipients of health service) have a psychological relationship with health care providers. This psychological relationship is stated by an informant who said that "he/she is only comfortable with certain medical officers", meaning he/she has been "suggested". The informant as a service provider also said that "if the patient has already been 'suggested', we can say that he/she is already halfway to get the cure and the medical staff only take care the halfway remains".

In line with the results of the study, the concept of the Health Belief Model by Becker (1980) in (Rosenstock, 1996) is indispensable in the delivery of health services. The concept is outlined in five aspects of thought from the internal of an individual that influences the effort to decide what is good for him/her. The thought was developed from 4 thoughts of (Edberg, 2007) with one more addition of cues to action. The whole thought is used for the purpose of self-efficacy (self-effort to determine what is good for him/her).

According to the results of the study, the concept of the Health Belief Model can be replicated and adopted in all types of public services not only limited to health services, especially for public services that have a choice (optional). Types of services that have a choice can be implemented by the government and the private sector. However, the concept of the Health Belief Model is less appropriate to be implemented at services monopolized by the government or services that have no option, meaning that the service is only carried out by the government, such as making land certificates, National ID cards, and others. Public participation to create government which is transparent, accountable, and innovative. (Ahmadi, Dadi, et al., 2019)

Public Service Assurance as a result of the research is one of the roles of information systems that are considered capable of increasing the belief toward public services which shape self-efficacy. This belief is influenced by 3 Dimensions of Information Systems in providing public services (Karno, I. Adi, B. Laksmono, 2018) as shown in figure 4.

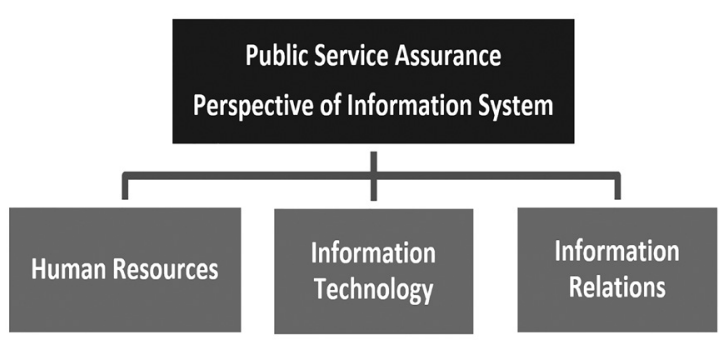

Figure 4. The Concept of Public Service
Assurance in Information Systems
Perspectives

Source: Researcher's processing result, Karno, 2014

Based on the concept of the constellation in figure 4, propositions can be arranged (Karno, I. Adi, B. Laksmono, 2018) as follows:

Human Resources include competencies, work performance, collaboration, and responsibilities of information systems management staff in delivering information services. Human resources information strengthens the Concept of Public Service Assurance in Information Systems Perspectives. This concept can be actualized by guaranteeing the ability to serve optimally, being polite and professional in serving, and can be trusted by the service recipient.

Information Technology includes information system hardware and software reliability, integration of information system hardware and software, and the effectiveness of information system application. This is an information service information technology that reinforces the Concept of Public Service Assurance in Information Systems Perspectives. This concept can be actualized 
by guaranteeing the ability to serve optimally, being polite and professional in serving, and can be trusted by the service recipient.

Information Relations include the relationship between the function of information system and the function of health service management, the function of information system in decision making for service managers, the function of information system in the implementation of service policies, and the function of information system in establishing relationships with service recipients. This is a service information relationship that reinforces the Concept of Public Service Assurance in Information Systems Perspectives. This concept can be actualized by guaranteeing the ability to serve optimally, being polite and professional in serving, and can be trusted by the service recipient.

The public services Assurance as a result of this study is not only related to the quality of services, but it is also necessary to add the concepts put forward by (Elizabeth \& Helen, 2006) as follows:

\footnotetext{
"Additionally, both QA and QE are distinguished from each other to show that they should be considered as two concepts of one continuum and that there is a need for both as ongoing processes"
}

The above opinion shows that guaranteeing public services requires Quality of Guarantee and Quality of Enhancement as two different concepts in one continuum. Both are needed in the process of sustainable public services in the management of public service organizations.

In line with the results of the study, the success or failure of public service Assurance is largely determined by information. This is in harmony with the concept of Information Management and Technology Strategy (IMTS) in UK National Health Services which states one of the system integrations that emphasizing improvement of communication and data accessibility within a strategic analysis framework. The strategic analysis and suitability framework of IMTS (Roberts, 1998 ) is applied to quality assurance (Service Assurance) in public services. In addition, technology also needs to be considered by public service providers/institutions (Elizabeth \& Helen, 2006). This is in line with the results of research which states that the information system is a dominant factor influencing public services as indicated by the amount of loading factor of 0.51 . That value is a manifestation of the loading factor value of Human Resources Information of 0.75; Information Technology of 0.70 ; and Information Relations of 0.82 . Thus, the dimensions of information systems that have a significant relationship are shown by loading factors greater than 0.50 as listed in table 2. These three dimensions must be integrated since they cannot run individually (Karno, I. Adi, B. Laksmono, 2018).

Public service Assurances are not only carried out now but should be run sustainably. This is in line with the following opinions:

\begin{abstract}
Service reforms for service quality are experiencing three waves based on strategies and approaches to service Assurance. The first focuses mainly on internal quality guarantee, The second emphasizes interface quality guarantee, and the third, emphasizes strongly future quality guarantee in terms of relevance to the new paradigm of service Assurance (Cheng, 2003).
\end{abstract}

The concept is in line with the results of a study by (Karno, I. Adi, B. Laksmono, 2018) who revealed public services assurance from an information systems perspective, namely the dimensions of the human resource of information as internal quality assurance, the dimension of information technology as an interface quality assurance and information relations as a future quality Assurance. This can be called the new paradigm of service Assurance.

Public services Assurances require the certainty of public service quality. The is in accordance with the following opinion:

Replacing Quality of Service (QoS) prediction
by Quality of Service Assurance (QoSA)
proposes a strategic change in the framework
of spectrum sharing. The theoretical analysis
of the QoSA approach and simulation results
show that the proposed approach will improve
the overall spectrum sharing efficiency.
QoSA significantly influences the successful
Secondary User (SU) operation in shared
bands (Sohul et al., 2014).

This opinion is in line with the theory of service quality (Zeithaml et al., 1990) as QoS in conceptual research that results in Service Assurances (Karno, I. Adi, B. Laksmono, 2018) as QoSA. Thus, QoSA can reach an efficient spectrum of public services.

The globalization and modern era as today are currently demanding public service Assurances in the context of improving quality Assurances for service organizations. Therefore, information technology is needed to collect, manage, analyze, and report a lot of quality Assurances data (service Assurance). 
In this context, it is necessary to develop a Quality Guarantee Management Information System) (Wolfe \& Tassé, 1979) as follows:

The evaluation of opportunities to use advanced Information Technology to enable outstanding customer service. The synthesize the Customer Service Life Cycle (CSLC) and the Customer Relationship Change Spectrum (CRCS). The CRCS enables managers to evaluate the organizational impact of proposed innovations. Combined two original models, the CSLC, and CRCS, to create a cohesive framework for systematically searching for opportunities to use IT to improve customer service. (Piccoli et al., 2005)

The opinion above shows that the two models can improve service to customers (community/people) as pointed out in figure 5 .

Social System Technical System
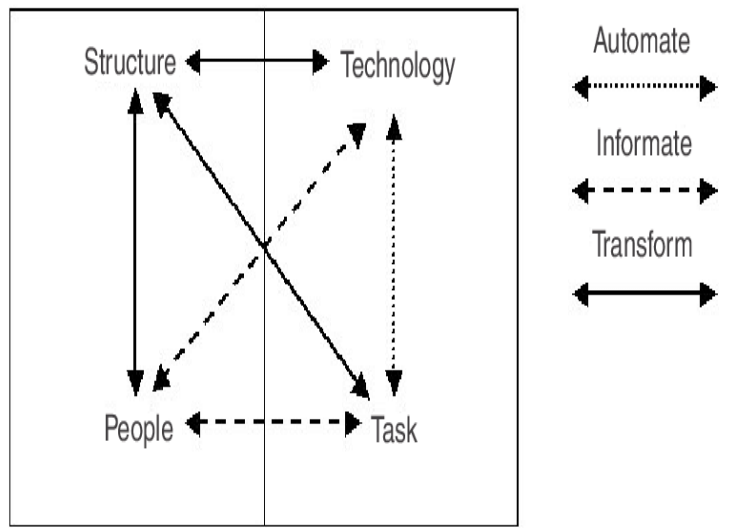

Figure 5

Customer Relationship Change Spectrum (CRCS)

Source: Adapted from O'Hara et al.,1999, (Piccoli et al., 2005)

Automate: Change Levels Definition. Changes how an established task is performed through the introduction of technology.

Informate: The role of the people performing the task changes, as well as the manner in which they interact with technology.

Transform: The organizational structure changes. Reporting structures and authority hierarchies are modified, new tasks are introduced, and the manner in which technology is selected, developed, and managed changes.

This opinion is in line with the results of the study by (Karno, I. Adi, B. Laksmono, 2018) which shows how important the dimension of information technology is in the information system variable in guaranteeing public services. As the research result indicated, the information technology dimension has a dominant loading factor, which means public service Assurances are strongly influenced by the information technology dimension. However, according to the results of the study, the information system is not yet optimal and still has weaknesses. This is indicated by the incompatible relationship between social systems and technical systems, such as Kedawung Puskesmas that have not fully applied technology in carrying out their duties (Piccoli et al., 2005).

\section{Conclusions}

The conclusion obtained based on the discussion above is that the information system has a significant influence on guaranteeing services to the community. In other words, the information system is a factor that determines the public services assurances. Thus, the information system that is able to provide Assurances of public services can construct the concept of the Digitalization of Public Service Assurances from Human Resources for Information, Information Technology, and Information Relations. Furthermore, the concept can be synthesized into a study of public services in scientific work.

\section{Acknowledgment}

We would like to thank our Institution (Institute of Governance of Home Affair), which has given permission and the opportunity for this research, we also do not forget to thank LPPM Unisba for helping to smooth the publication of this research.

\section{References}

Aagja, J. P., \& Garg, R. (2010). Measuring perceived service quality for public hospitals (PubHosQual) in the Indian context. International Journal of Pharmaceutical and Healthcare Marketing. https://doi. org/10.1108/17506121011036033.

Ahmadi, Dadi, Rachmiatie, A., \& Nursyawal. (2019). Public participation model for public information disclosure. Jurnal Komunikasi: Malaysian Journal of Communication, 35(4), 305-321. https:// doi.org/10.17576/JKMJC-2019-3504-19

Agamba, J., \& Keengwe, J. (2012). PreService Teachers' Perceptions of Information Assurance and Cyber Security. International Journal of Information and 
Communication Technology Education, 8(2), 94-101. https://doi.org/10.4018/ jicte. 2012040108

Ayanso, A., Cho, D. I., \& Lertwachara, K. (2010). The digital divide: Global and regional ICT leaders and followers. Information Technology for Development, 16(4), 304-319. https://doi.org/10.1080 /02681102.2010.504698.

Basudewa, M. I., Bagaskara, Z. H., Damita, S. S. A., Putra, R. F., \& Ahmadi, D. (2020). Bit Error Rate performance analysis for Free Space Optic communication. IOP Conference Series: Materials Science and Engineering, 850(1). https://doi. org/10.1088/1757-899X/850/1/012056

Bodnar, H. G. dan W. S. H. (2000). Sistem Informasi Akuntansi (P. A. A. J. dan R. M. Tambunan (ed.)). Salemba Empat.

Cheng, Y. C. (2003). Quality Assurance In Education: Internal, Interface, And Future. Quality Assurance in Education, 11(4), 202-213. https://doi. org/10.1108/09684880310501386

Edberg, M. (2007). Buku Ajar Kesehatan Masyarakat : teori sosial dan perilaku (Essential of Health Behavior : Social and Behavioral Theory in Public Health.

Elizabeth, V., \& Helen, W.-B. (2006). Quality Assurance in Education Article information : Quality Assurance in Education, 14(3), 251-267. https://doi.org/http://dx.doi. org/10.1108/QAE-11-2012-0046

Gray, J., \& Rumpe, B. (2015). Models for digitalization. Software and Systems Modeling, 14(4), 1319-1320. https://doi. org/10.1007/s10270-015-0494-9

Grossman, G., Platas, M. R., \& Rodden, J. (2018). Crowdsourcing accountability: ICT for service delivery. World Development, 112, 74-87. https://doi.org/10.1016/j. worlddev.2018.07.001

ICT. (2015). ICT Facts \& Figures. The world in 2015. Telecommunication Development Bureau, 6. https://doi. org/10.1787/9789264202085-5-en

Indrajit, R. E. (2004). Kajian Strategis Cost Benefit Teknologi Informasi. Andy offset.

Jogiyanto, H. (1995). Analisis dan desain. Andi offset.

Johnson, R. B., \& Onwuegbuzie, A. J. (2004). Mixed Methods Research: A Research Paradigm Whose Time Has Come. Educational Researcher, 33(7), 14-26. https://doi. org/10.3102/0013189X033007014

Kang, G. Du, \& James, J. (2004). Service quality dimensions: An examination of Grönroos's service quality model.
Managing Service Quality: An International Journal, 14(4), 266-277. https://doi. org/10.1108/09604520410546806

Karno. (2014). Analisis Pengaruh Organisasi dan Individu Terhadap Kualitas Pelayanan Puskesmas. Universitas Indonesia.

Karno, Adi, I. R., \& Laksmono, B. S. (2018). Analisis Pengaruh Faktor Organisasi Dan Faktor Individu Terhadap Kualitas Pelayanan Puskesmas Studi Pada Puskesmas Kecamatan Kedawung Ka. K., Adi, I. R., \&Amp; Laksmono, B. S. (2018). Analisis Pengaruh Faktor Organisasi Dan Faktor Individu Terhadap Kualit.

Jurnal IImu Kesejahteraan Sosial, 18(1). https://doi.org/10.7454/jurnalkessos. v18i1.101

Kim, Y.-K., \& Oh, H.-J. (2012). Causality Analysis on Health Care Evaluation Criteria for State-Operated Mental Hospitals in Korea Using Malcolm Baldrige National Quality Award Model. Community Mental Health Journal, 48(5), 643-651.

McLoad. (1996). Sistem Informasi Manajemen (Jilid 1). H. Prehanllindo.

Morrar, R., \& Arman, H. (2017). The Fourth Industrial Revolution (Industry 4.0): A Social Innovation Perspective. Technology Innovation Management Review, 7(11), 12-20. https://doi.org/10.22215/ timreview/1117

Mosadeghrad, A. M. (2014). Factors Affecting Medical Service Quality. Iranian Journal of Public Health.

Neuman, W. L. (2006). Science and research. In Social research methods : qualitative and quantitative approaches (pp. 1-22). https://doi.org/10.1002/pfi.4140440310

Ograjenšek, I. (2008). Service Quality. In Statistical Practice in Business and Industry (pp. 117-136). https://doi. org/10.1002/9780470997482.ch6

Pemda Sragen. (2008). Kabupaten Sragen Dalam Angka 2008.

Piccoli, G., Anglada, L. D., \& Watson, R. T. (2005). Using Information Technology to Improve Customer Service. Journal of Quality Assurance in Hospitality \& Tourism, 5(1), 3-26. https://doi.org/10.1300/ J162v05n01_02.

Rachmiatie, A., Hasbiansyah, O., Khotimah, E., \& Ahmadi, D. (2013). Strategi Komunikasi Politik dan Budaya Transparansi Partai Politik. MIMBAR, Jurnal Sosial Dan Pembangunan, 29(2), 123. https://doi. org/10.29313/mimbar.v29i2.384

Roberts, C. (1998). Quality assurance in primary care with information management and technology. Health Informatics 
Journal, 4(2), 101-105. https://doi. org/10.1177/146045829800400207

Rosenstock, L. (1996). The future of intervention research at NIOSH. In American Journal of Industrial Medicine (Vol. 29, Issue 4, pp. 295-297). https://doi.org/10.1002/(SICI)10970274 (199604)29:4<295: : A ID AJIM3>3.0.CO;2-O

Roses, L. K., Hoppen, N., \& Henrique, J. L. (2009). Management of perceptions of information technology service quality. Journal of Business Research, 62(9), 876-882. https://doi.org/10.1016/j. jbusres.2008.10.005

Sharma, A. (2007). Opportunities of international E-services: A conceptual model. In E-Services: Opportunities and Threats (pp. 63-77). https://doi. org/10.1007/978-3-8350-9614-1_5

Sohul, M. M., Ma, X., Yang, T., \& Reed, J. H. (2014). Quality of service assurance for shared spectrum systems. Proceedings IEEE Military Communications Conference MILCOM, 1471-1476. https://doi. org/10.1109/MILCOM.2014.243

Taherdoost, H., Sahibuddin, S., \& Jalaliyoon, N. (2013). E-Services Usage Evaluation;
Applications' level of Co-Creation and Digitalization. International Journal of Academic Research in Management, 2(1), 10-18. http://ssrn.com/ abstract $=2371011$

Tashakkori, A., \& Teddlie, C. (2010). Sage handbook of mixed methods in social \& behavioral research. Sage.

Valaskakis, O. for E. C. and D. (OECD) P. S. (2011). Governing in the 21st century. In IT Professional. https://doi.org/10.1109/ MITP. 2011.48

Wijanto, S. (2008). structural equation modeling dengan LISREL 8.8.2 konsep dan tutorial. In structural equation modeling dengan LISREL 8.8.2 konsep dan tutorial (p. 61). https://doi.org/10.1016/j. ocecoaman.2012.11.005

Wolfe, P. M., \& Tassé, S. (1979). Development of a quality assurance management information system. International Journal of Production Research, 17(3), 169-180. https://doi. org/10.1080/00207547908919605

Zeithaml, V. A., Parasuraman, A., Berry, L. L., \& Berry, L. L. (1990). Delivering quality service: Balancing customer perceptions and expectations. Simon and Schuster. 